\title{
Protective Effect of Green Tea Against Dimethylnitrosamine Induced Genotoxicity in Mice Bone Marrow Cells
}

\author{
Zarrag Isa Al-Fify ${ }^{1}$ and Magdy Sayed Aly ${ }^{*}, 1,2$ \\ ${ }^{I}$ Biology Department, Faculty of Science, Jazan University, Saudi Arabia \\ ${ }^{2}$ Zoology Department, Faculty of Science, Beni Suef University, Egypt
}

\begin{abstract}
Cancer is a major cause of death in the world; thus, the prevention of this disease would have a significant impact on public health. Chemoprevention is defined as natural and synthetic pharmacological (chemical) agent to disrupt the process of carcinogenesis. Green tea is a potent chemopreventive agent in many test systems and has been shown to inhibit tumor promotion and induce apoptosis. It is one of the most frequently consumed beverages in the world. Green tea polyphenolics have demonstrated antimutagenic, anticarcinogenic, antioxidant and antipromotional effects.
\end{abstract}

The aim of this work is to study the protective effect of green tea extract against genotoxic damage of dimethylnitrosamine (DMN) in mice bone marrow cells.

Our results demonstrated that the administration of green tea extract $24 \mathrm{hr}$ before the DMN injection significantly suppressed DMN-induced chromosomal aberrations and sister chromatid exchanges. The suppression was observed $18 \mathrm{hr}$, $24 \mathrm{hr}$ and $48 \mathrm{hr}$ after the DMN treatment but no suppressive effect was observed at the early period $(6 \mathrm{hr}$ and $12 \mathrm{hr}$ ) after the DMN treatment. Furthermore, the suppression was observed in all doses of DMN $(4,5$ and $6 \mathrm{mg} / \mathrm{kg})$ investigated. Mice were given green tea $2 \mathrm{hr}$ before the DMN injection displayed no suppressive effect.

Mice were given $2 \%$ green tea extract as the sole source of drinking water for four days before sacrifice displayed significantly suppressed DMN-induced chromosomal aberrations and sister chromatid exchanges.

We conclude that green tea presents significant antigenotoxic concern under the anticipated conditions of use. These results are consistent with other antigenotoxicity studies of green tea.

Keywords: Dimethylnitrosamine, chromosomal aberration, sister chromatid exchanges, mice bone marrow cell, green tea.

\section{INTRODUCTION}

Chemoprevention is a mean of cancer control in which disease occurrence is prevented by the administration of one or a combination of several chemical agents. One of the exciting findings in this area of research is the identification of a large number of compounds with great structural diversity, which have shown a promise in several animal bioassay systems. One of the most impressive finding in this field is the presence of these compounds in the human diet, which would make it possible that a simple changes in dietary habits could significantly lower cancer risk.

Tea (Camellia sinensis) is one of the most popular beverages consumed worldwide and has a whole history of consumption dating from ancient times. Among the various types of tea, green tea contains relatively a high level of polyphenols, which consists of flavanol monomers (flavan3-ols), also referred to as catechins. Tea catechins have garnered considerable attention as a result of beneficial effects on health, such as their observed antioxidant activity [1] and anti-viral activity [2], as well as their ability to serve as an anti-plaque forming agent [3], anti-carcinogenic agent [4-7],

*Address correspondence to this author at the Zoology Department, Faculty of Science, Beni Suef University, Egypt; Tel: +20105252234; E-mail: magdyaly@yahoo.com anti-cardiovascular disease agent [8], hypotensive agent [9], hypocholesterogenic agent [10], and blood sugar reductive agent [11]. Recently, the ingestion of tea catechins or tea beverage enriched with catechins has shown to be effective in reducing body fat [12]. Although the mechanism of action for this effect is not known, it is thought to be due to the stimulation of lipid catabolism in the liver [13] and/or the enhancement of energy consumption [14]. Based on these findings, a catechin-rich tea beverage that claims to have a preventive effect on body fat accumulation has been marketed in Japan as a "Food for Specified Health Use." During the manufacture of catechin-rich beverages, green tea extract is prepared from green tea leaves and then formulated into beverages. The green tea catechins consist of isomers including catechin $(\mathrm{C})$, catechin gallate $(\mathrm{Cg})$, gallocatechin (GC), gallocatechin gallate (GCg), epicatechin (EC), epicatechin gallate (ECg), epigallocatechin (EGC), and epigallocatechin gallate (EGCG). When subjected to high heat conditions, tea catechin monomers undergo epimerization [15]. Hence, the composition of catechin isomers in beverages varies, primarily according to the heat-sterilization conditions employed during the manufacturing process. The heat sterilization conditions for different beverages are determined based on certain characteristics of the beverage, including $\mathrm{pH}$ and packaging; thus, the relative epimerization of catechins is greater in certain beverages. Regarding the genotoxic aspects of tea catechins, many studies have demons- 
trated that tea catechins could suppress the genotoxic activity of various carcinogens with both in vitro and in vivo systems [16-23]. As to the genotoxic profile of tea catechins when tested alone, Chang et al. [24] have shown that there is minimal genotoxic concern with a decaffeinated green tea catechin mixture (Polyphenon E) that contains about 50\% epigallocatechin gallate and $30 \%$ other catechins. Isbrucker et al. [25] have also found no genotoxic concern with a epigallocatechin gallate (GTE) preparation, Teavigo.

Nitrosamines have been intensively studied as a large class of chemical carcinogens [26]. Their carcinogenic activity is a subject of serious concern because of widespread human exposure to this group of compounds, which are commonly found in our diet and environment and can be synthesized endogenously [26-29].

The aim of the present study was to access the antigenotoxic effect of green tea against dimethylnitrosamine $(\mathrm{DMN})$, in order to reduce its genotoxic effects. These effects were studied in mice bone marrow cells in vivo.

\section{MATERIAL AND METHODS}

\section{Preparation of 2\% Green Tea Extract (GTE)}

Twenty gm green tea leaves (Karigane Sencha, Ito En Co., Tokyo, Japan) were added to 1 lit (Ambiguity in the sentence, author assistance required) of boiling water and were steeped for 10 minute. The infusion was cooled to room temperature and then filtered to obtain $2 \%$ green tea infusion ( $2 \mathrm{~g}$ green tea leave/100 $\mathrm{ml}$ of water).

\section{Experimental Animals}

Random bred male mice (Mus musculus) aged 3-5 months were provided by the Research Institute of Ophthalmology, Cairo University, Cairo. Food and water were given ad libitum.

Dimethylnitrosamine (DMN, Sigma, St. Louis, USA) was used as a carcinogenic agent; it was dissolved in $\mathrm{H}_{2} \mathrm{O}$ and injected intraperitoneally with three different concentrations (4, 5 and $6 \mathrm{mg} / \mathrm{kg}$ body weight). Groups of mice (5 animals/ group) were treated at different time. A control group received only the vehicle solution.

In the first experiment, individual green tea extract was administered by gastric instillation to lightly ether- anesthetized mice at various times before the DMN injection. Colchicine $(4 \mathrm{mg} / \mathrm{kg})$ was injected i.p. $1 \mathrm{hr}$ before sacrifice. Chromosome specimens were prepared from the femoral bone marrow by the conventional method at various times after the DMN injection, stained in $2 \%$ Giemsa solution $(\mathrm{pH}$ 6.8) for $15 \mathrm{~min}$, and then analyzed microscopically. In experiment 2 , mice were administered $2 \%$ green tea extract as the sole source of drinking water for four days before sacrifice. The other protocol is the same as that in experiment 1 .

\section{Chromosome Analysis}

Metaphase cells with one or more chromosomal aberrations were scored from 50 well-spread metaphases per mouse (therefore 250 metaphases per each experimental group). Gaps were defined as achromatic lesions in one or both chromatids not exceeding the width of a chromatid, and the gap breaks as a discontinuity greater than the width of a chromatid, irrespective of whether or not the distal fragment was dislocated. Cells with multiple chromosomal aberrations were defined as cells in which the number of chromosomal aberrations was too many to count (numerous, above 10). Cells were classified according to the most severe damage out of chromosomal aberrations which had occurred in a cell and were placed in only 1 of 4 categories: cells with gaps only, cells with breaks, cells with exchanges, and cells with multiple chromosomal aberrations. In the tabulated data, the column headed "percentage of aberrant cells" gives the percentage of damaged cells in the total population of cells analyzed. Damaged cells include the cells with breaks, exchanges and multiple chromosomal aberrations, but not the cells with gaps. The severity of damage within a cell is also given as the number of aberrations per cell; cells with multiple chromosomal aberrations were counted as 10 aberrations. The suppression rate was calculated from the frequency of aberrant cells.

\section{Sister Chromatid Exchange Assay}

Paraffin-coated Bromodeoxyuridine (BrdUrd) tablets (50 mg; Boehringer Mannhein Biochemicals, Indianapolis, IN) were inserted under the skin. At $16 \mathrm{~h}$ after BrdUrd implantation DMN was injected. Five hours after DMN treatment, animals were given injections of colchicine $(4 \mathrm{mg} / \mathrm{kg}$ GIBCO) and were sacrificed by cervical dislocation $3 \mathrm{~h}$ later. Hypotonic treatment and fixation were performed in the same way as for chromosomal aberrations analysis.

Staining for sister chromatid exchanges analysis was performed according to a modified technique of Perry and Wolff [30] and Afzal and Azfer [31]. Slides were stained for $15 \mathrm{~mm}$ with Hoechst $33258(5 \mu \mathrm{g} / \mathrm{ml})$ and exposed to "black" light at $55-60^{\circ} \mathrm{C}$ for $15 \mathrm{~cm}$ at a distance of $1 \mathrm{~cm}$ while immersed in Sorenson's buffer (phosphate buffer, $\mathrm{pH}$ 6.8). The slides were then rinsed with distilled water and stained with 5\% Giemsa (in Sorenson's buffer) for 10-15 min. All slides were coded, and cells with at least 38 chromosomes were analyzed for sister chromatid exchanges.

To determine replicative index, the frequencies of the first, second, and third subsequent metaphases were determined in 100 consecutive metaphase cells from each of the 5 animals. Those cells whose DNA had replicated exclusively before the addition of BrdUrd could not be distinguished from cells at first metaphase, and those that had gone through 3 or more cell cycles were included as third mitoses. The replicative index was calculated as follows:

$$
\mathrm{RI}=\frac{1 \mathrm{M}_{1}+2 \mathrm{M}_{2}+3 \mathrm{M}_{3}}{100}
$$

where $M_{1}, M_{2}$, and $M_{3}$ represent percentages of first, second, and third metaphases, respectively.

\section{Statistical Analysis}

For chromosomal aberrations analysis, Chi-square test (2X2 contingency table) was used, whereas, the t-test of the difference between means was used for sister chromatid exchanges, and replicative index data analysis. 


\section{RESULTS}

The present study was designed to investigate the possible protective role of green tea on bone marrow cells of mice treated with different concentrations of dimethylnitrosamine $(\mathrm{DMN})$

The cytogenetic effect was measured by two end points, chromosomal aberrations and sister chromatid exchanges.

DMN-induced chromosomal aberrations consisted mainly of gaps and breaks (Fig. 1). Cells with multiple chro-

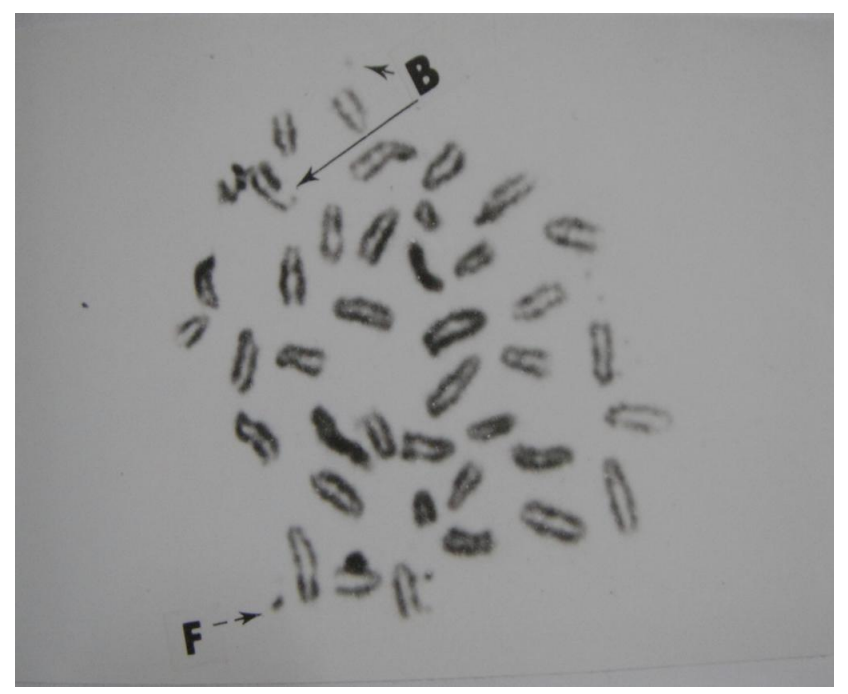

Fig. (1). Metaphase spread from mouse bone marrow cells showing chromosomal aberrations after injection with DMN

mosomal aberrations or exchanges were observed infrequently. On the other hand, the mice which had received distilled water without DMN showed only a few gaps and breaks in their bone marrow cells. Cells with exchange or multiple chromosomal aberrations were not observed. The frequency of aberrant cells in the bone marrow of mice injected with DMN became higher with the lapse of time as did the number of aberrations per cell. They were at their maximum levels $18 \mathrm{hr}$ after the DMN injection. After that, they decreased with the lapse of time (Table 1). The frequency of aberrant cells induced by DMN increased in proportion to the dose of DMN. Mice given GTE $24 \mathrm{hr}$ before the DMN injection displayed a considerably suppressed frequency of DMN-induced chromosomal aberrations in their bone marrow cells. The suppression was observed 18 $\mathrm{hr}, 24 \mathrm{hr}$ and $48 \mathrm{hr}$ after the DMN injection but no suppressive effect was observed at the early period $(6 \mathrm{hr}$ and $12 \mathrm{hr}$ ) after the DMN injection. The number of aberrations per cell also showed the same tendency as the frequency of aberrant cells (Table 1). The significant suppression by GTE was observed in all doses $(4,5$, or $6 \mathrm{mg} / \mathrm{kg})$ of DMN investigated.

Mice given GTE $2 \mathrm{hr}$ before the DMN injection showed no suppressive effect and the maximum suppression was observed in mice given GTE $24 \mathrm{hr}$ before the DMN injection. Mice given only GTE without carcinogen displayed no induction of chromosomal aberrations in their bone marrow cells (data not shown). Mice given $2 \%$ green tea infusion as the sole source of drinking water for four days before sacrifice displayed significantly suppressed DMN-induced chromosomal aberrations.

The data on the in vivo induction of SCEs in bone marrow following animal exposure to GTE and DMN are given in Table 2. The data represents 2 separate experiments with at least 2 animals in each experiment. Both experiments were performed under identical conditions. However, it caused a dose related decrease in $\mathrm{DMN}$-induced sister chromatid exchanges at all concentrations tested as the same

Table 1. Variation in Course of Time of DMN-Induced Chromosomal Aberrations in the Bone Marrow Cells of mice Receiving only DMN Injection or both Green Tea Extract Pretreatment and DMN Injection ${ }^{\text {a) }}$

\begin{tabular}{|c|c|c|c|c|c|c|c|}
\hline \multirow{2}{*}{ Time (hr) } & \multirow{2}{*}{ Treatment } & \multicolumn{3}{|c|}{ Percentage of Cells with } & \multirow{2}{*}{ No. } & \multirow{2}{*}{ ( } \\
\cline { 3 - 6 } & & Gap & Break & Ex. & Multi. & \multirow{2}{*}{ Percentage of Aberrant Cells ${ }^{\text {c) }}$} \\
\hline \hline \multirow{2}{*}{0} & Non- DMN & $1.8 \pm 0.5$ & $0.8 \pm 1.0$ & $0.0 \pm 0.0$ & $0.0 \pm 0.0$ & $0.01 \pm 0.01$ & $0.8 \pm 1.0$ \\
\hline \multirow{2}{*}{6} & DMN only & $8.5 \pm 3.4$ & $16.1 \pm 5.8$ & $0.1 \pm 0.3$ & $0.2 \pm 0.4$ & $0.32 \pm 0.16$ & $16.3 \pm 5.7$ \\
& GTE+DMN & $8.7 \pm 1.9$ & $18.1 \pm 5.1$ & $0.0 \pm 0.0$ & $0.2 \pm 0.4$ & $0.38 \pm 0.19$ & $18.4 \pm 5.2(-12)$ \\
\hline \multirow{2}{*}{12} & DMN only & $10.0 \pm 2.6$ & $22.0 \pm 4.0$ & $0.1 \pm 0.3$ & $0.5 \pm 0.8$ & $0.47 \pm 0.24$ & $22.7 \pm 4.3$ \\
& GTE+DMN & $9.2 \pm 1.3$ & $21.8 \pm 4.5$ & $0.4 \pm 0.5$ & $0.8 \pm 0.8$ & $0.56 \pm 0.27$ & $23.0 \pm 5.3(-1)$ \\
\hline \multirow{2}{*}{18} & DMN only & $13.6 \pm 2.3$ & $28.2 \pm 4.3$ & $0.2 \pm 0.4$ & $1.2 \pm 1.0$ & $0.66 \pm 0.20$ & $29.6 \pm 4.8$ \\
& GTE+DMN & $10.4 \pm 1$ & $17.0 \pm 4.9$ & $0.2 \pm 0.4$ & $0.0 \pm 0.0$ & $0.44 \pm 0.19$ & $17.2 \pm 5.2(42)^{* *}$ \\
\hline \multirow{2}{*}{48} & DMN only & $9.2 \pm 2.0$ & $21.7 \pm 2.1$ & $0.3 \pm 0.5$ & $0.5 \pm 0.8$ & $0.43 \pm 0.13$ & $22.5 \pm 3.1$ \\
& GTE+DMN & $10.6 \pm 1.7$ & $15.4 \pm 4.9$ & $0.2 \pm 0.4$ & $0.2 \pm 0.4$ & $0.32 \pm 0.15$ & $16.0 \pm 4.7(29)^{*}$ \\
\hline \multirow{2}{*}{72} & DMN only & $6.8 \pm 1.3$ & $11.2 \pm 4.0$ & $0.2 \pm 0.4$ & $0.0 \pm 0.0$ & $0.13 \pm 0.04$ & $11.4 \pm 4.0$ \\
& GTE+DMN & $5.1 \pm 2.3$ & $7.5 \pm 3.1$ & $0.0 \pm 0.0$ & $0.0 \pm 0.0$ & $0.11 \pm 0.08$ & $7.5 \pm 3.1(34)^{*}$ \\
& DMN only & $3.2 \pm 1.8$ & $2.8 \pm 0.8$ & $0.0 \pm 0.0$ & $0.0 \pm 0.0$ & $0.03 \pm 0.01$ & $2.8 \pm 0.8$ \\
& GTE+DMN & $2.5 \pm 1.0$ & $1.5 \pm 1.5$ & $0.0 \pm 0.0$ & $0.0 \pm 0.0$ & $0.02 \pm 0.02$ & $1.5 \pm 1.5(46)$ \\
\hline
\end{tabular}

${ }^{a)}$ Chromosome specimens were prepared at various times after $6 \mathrm{mg}$ DMN/kg body weight was injected. GTE was given $24 \mathrm{hr}$ before the DMN injection. Values are means \pm S.D for 5 mice.

b) Ex., exchange; Multi., multiple chromosomal aberrations: cells having more than 10 aberrations.

${ }^{c}$ Cells with gaps are not included in the percentage of aberrant cells. Figures in the parenthesis indicate the suppression rate.

Significantly different from the mice group given only DMN: $* * p<0.01, * p<0.05$. 
Table 2. Effect of GTE on DMN-Induced Sister Chromatid Exchanges in Mice Bone Marrow Cells in vivo. At Least 4 Animals were Used for each Treatment, and 25 Second Division Metaphases were Scored for Sister Chromatid Exchanges from each Animal. For Replicative Index, 100 Consecutive Metaphases were Scored for $M_{1}, M_{2}$, and $M_{3}$ or more Cell Divisions from each Animal

\begin{tabular}{|c|c|c|c|}
\hline \multirow{2}{*}{ Time (hr) } & \multirow{2}{*}{ Treatment } & \multicolumn{2}{|c|}{ Bone Marrow ${ }^{a}$} \\
\hline & & Sister Chromatid Exchange' / Cell & Replicative Index \\
\hline 0 & Non- DMN ${ }^{b}$ & $3.36 \pm 0.24^{\mathrm{c}}$ & $2.04 \pm 0.06$ \\
\hline \multirow{2}{*}{6} & DMN only & $7.59 \pm 0.29$ & $2.00 \pm 0.04$ \\
\hline & GTE+DMN & $9.49 \pm 0.23$ & $3.12 \pm 0,43$ \\
\hline 12 & DMN only & $18.41 \pm 0.95$ & $1.97 \pm 0.03$ \\
\hline \multirow{2}{*}{18} & DMN only & $23.40 \pm 0.94$ & $2.04 \pm 0.06$ \\
\hline & GTE+DMN & $12.12 \pm 0.07$ & $1.45 \pm 0,61$ \\
\hline \multirow{2}{*}{24} & DMN only & $21.92 \pm 1.47$ & $1.97 \pm 0.06$ \\
\hline & GTE+DMN & $11.86 \pm 0.13$ & $1.33 \pm 0.01$ \\
\hline 48 & DMN only & $14.02 \pm 1.19$ & $2.02 \pm 0.11$ \\
\hline
\end{tabular}

${ }^{\mathrm{a}}$ The decrease in sister chromatid exchanges with increased concentration of GTE with DMN was significant $(\mathrm{P}<0.01)$.

${ }^{b}$ Distilled water

${ }^{\mathrm{c}}$ Mean $\pm \mathrm{SD}$

manner for chromosomal aberrations. The frequency of sister chromatid exchanges in the bone marrow of mice injected with DMN became higher with the lapse of time. They were at their maximum levels $18 \mathrm{hr}$ after the DMN injection (Fig. 2). After that, they decreased with the lapse of time (Table 2). The frequency of sister chromatid exchanges induced by DMN increased in proportion to the dose of DMN. Mice given GTE $24 \mathrm{hr}$ before the DMN injection displayed a considerably suppressed frequency of DMN-induced sister chromatid exchanges in their bone marrow cells. The suppression was observed $18 \mathrm{hr}, 24 \mathrm{hr}$ and $48 \mathrm{hr}$ after the DMN injection but no suppressive effect was observed at the early period ( $6 \mathrm{hr}$ and $12 \mathrm{hr}$ ) after the DMN injection.

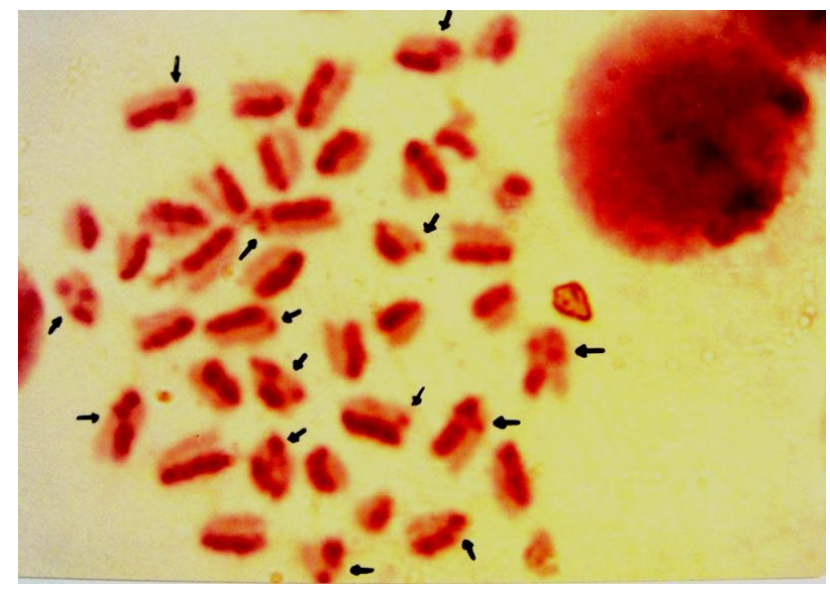

Fig. (2). Metaphase spread from mouse bone marrow cells showing sister chromatid exchanges.

Mice given only GTE without carcinogen displayed no induction of sister chromatid exchanges in their bone marrow cells (data not shown). Mice given $2 \%$ green tea infusion as the sole source of drinking water for four days before sacrifice displayed significantly suppressed DMNinduced sister chromatid exchanges.

The data on cell replication kinetics are shown in Table 2. The replicative index of cells from treated animals was almost similar to the respective control values. However, GTE caused significant cell cycle delay and toxicity.

\section{DISCUSSION}

Nitrosamines have been intensively studied as a large class of chemical carcinogens [26]. Their carcinogenic activity is a subject of serious concern because of widespread human exposure to this group of compounds, which are commonly found in our diet and environment and can be, synthesized endogenously [26-29]. In vivo and in vitro treatments with DMN induce a broad spectrum of genotoxic effects: chromosomal aberrations (CA) in Chinese hamster V79 cells, point mutations in the Ames test and sister-chromatid exchanges (SCE) in mouse bone marrow and V79 cells [32, 33]. Additional biological effects are immunosupression of murine splenocytes and hepatocytes [34, 35] and cell-cycle delays in mouse maternal and fetal cells [36].

In the present study, we have investigated the suppressive effect of green tea, on DMN-induced chromosomal aberrations and sister chromatid exchanges in mouse bone marrow cells. These genotoxic endpoints are well known markers of genotoxicity and any reduction in the frequency of these genotoxic endpoints gives us an indication of the antigenotoxicity of a particular compound [37]. Sister chromatid exchange is usually a more sensitive indicator of genotoxic effects than chromosomal aberrations [38]. There is a correlation between the carcinogenicity and sister chromatid exchange inducing ability of many chemicals. Moreover, the 
sister chromatid exchange induction mechanism is heterogeneous and very different from the mechanism of chromosomal aberrations induction [39]. Sister chromatid exchanges are reciprocal interchanges of DNA replication products at homologous sites between 2 chromatid arms within a single chromosome in dividing cells [40, 41]. These interchanges occur spontaneously in all cells at a low rate, and the rate of their formation increases when DNA is damaged and/or improperly repaired. SCEs can be detected after incorporating bromodeoxyuridine (BrdU) into chromosomal DNA for 2 cell cycles. There is a little information available on the exact reasons for the genotoxic behavior of DMN.

The administration of GTE $24 \mathrm{hr}$ before the DMN injection potently suppressed DMN-induced genotoxicity. The suppression mechanism of GTE has not been elucidated as yet. It has been previously reported [42, 43] that the administration of sudan III, an inducer of drug-metabolizing enzymes, $24 \mathrm{hr}$ before a carcinogen treatment potently suppressed carcinogen-induced chromosomal aberrations, although its administration $2 \mathrm{hr}$ before did not. The suppression of 7,12-dimethylbenz( $a$ )anthracene (DMBA)-induced chromosomal aberrations by sudan III was observed at all periods after the DMBA treatment. It was suggested that the suppressive effect of sudan III is due to the induction of cytochrome P450 and GST by sudan III in mouse liver. Furthermore, it has been previously reported $[42,44,45]$ that glutathione (GSH), ellagic acid and S-methyl methane thiosulfonate (MMTS), not an inducer of drug-metabolizing enzymes, significantly suppressed carcinogen-induced chromosomal aberrations, but their suppressive effect was maximum when given $2 \mathrm{hr}$ or $30 \mathrm{~min}$ before the carcinogen treatment. The suppression of DMN- or methyl methane sulfonate (MMS)-induced chromosomal aberrations by MMTS was also observed at all periods after the carcinogen treatment. Moreover, it was suggested that the suppression of carcinogen-induced chromosomal aberrations by GSH or ellagic acid results from the direct reaction with the active metabolite of carcinogen and that the suppression by MMTS results from the ability of MMTS to modify - SH group in proteins. The suppression of DMN-induced genotoxicity by GTE was observed only at the late period (18, 24 and $48 \mathrm{hr}$ ) after the DMN injection. This result is different from the previous result showing that sudan III and MMTS suppressed carcinogen-induced chromosomal aberrations at all periods after the carcinogen treatment. Therefore, this result may suggest that the administration of GTE accelerates the rate of DMN metabolism in mouse liver and that the decrease of active metabolites of DMN reaching target cells produces the suppression of DMN-induced chromosomal aberrations at the late period after the DMN injection. Therefore, our results mentioned above may suggest that the suppression mechanism of GTE has two different ways depending on the administration time and the kind of GTE. Kada [46] divided antimutagens into desmutagen and bioantimutagen according to their modes of action. The former inactivates or destroys mutagens directly or indirectly outside the cell and the latter suppresses the process of mutagenesis itself inside the cell. The present results may show that GTE suppresses DMN-induced genotoxicity in a desmutagenic manner because the administration of GTE to mice previously exposed to DMN showed no suppression (data not shown). Jain et al. [47] also reported that GTE and
GTP, such as EC, ECG and EGC decreased the mutagenic activity of $N$-methyl- $N^{\prime}$-nitro- $N$-nitrosoguanidine to $E$. coli WP2 in vitro in a desmutagenic manner. However, Kada et al. [46] reported that GTE has a bio-antimutagenic activity, that is, GTE improves the fidelity of DNA replication. Sasaki et al. [48, 49] and Shimoi et al. [50] also reported that tannic acid obtained by hydrolysis from gallotannin is a bioantimutagen that enhances the excision repair activity. However, the present study indicates that mice given $2 \%$ green tea extract for four days significantly displayed suppressed DMN-induced genotoxicity.

The present study is consistent with several epidemiological studies suggesting that the habitual drinking of green tea decreases the incidence of certain types of cancer. However, some serious problems, such as the toxicity of GTE or its metabolites, remain in considering them as a cancer chemopreventive agent. Especially their metabolism has not yet been elucidated at all. Further studies are needed for clarification.

\section{REFERENCES}

[1] Yoshino K, Hara Y, Sano M, Tomita I. Antioxidative effects of black tea theaflavins and thearubigin on lipid peroxidation of rat liver homogenates induced by tert-butyl hydroperoxide. Biol Pharm Bull 1994; 17: 146-9.

[2] Nakayama M, Suzuki K, Toda M, Okubo S, Hara Y, Shimamura T. Inhibition of the infectivity of influenza virus by tea polyphenols. Antiviral Res 1993; 21: 289-99.

[3] Hattori M, Kusumoto IT, Namba T, Ishigami T, Hara Y. Effect of tea polyphenols on glucan synthesis by glucosyltransferase from Streptococcus mutans. Chem Pharm Bull 1990; 38: 717-20.

[4] Bemis DL, Katz AE, Buttyan R. Clinical trials of natural products as chemopreventive agents for prostate cancer. Expert Opin Investig Drugs 2006; 15: 1191-200.

[5] Katiyar SK, Mukhtar H. Tea in chemoprevention of cancer: Epidemiologic and experimental studies (Review). Int $\mathrm{J}$ Oncol 1996; 8: 221-38.

[6] Lee AH, Fraser ML, Meng X, Binns CW. Protective effects of green tea against prostate cancer. Expert Rev Anticancer Ther 2006; 6: 507-13.

[7] Yuan JM, Gao YT, Yang CS, Yu MC. Urinary biomarkers of tea polyphenols and risk of colorectal cancer in the Shanghai Cohort study. Int J Cancer 2007; 120: 1344-50.

[8] Wolfam S. Effects of green tea and EGCG on cardiovascular and metabolic health. J Am Coll Nutr 2007; 26: 373-88.

[9] Henry JP, Stephens-Larson P. Reduction of chronic psychosocial hypertension in mice by decaffeined tea. Hypertension 1984; 6: 437-44.

[10] Ikeda I, Imasato Y, Sasaki E, Nakayama M, Nagao H, Takeo T, Ayabe F, Sugano M. Tea catechins decrease micellar solubility and intestinal absorption of cholesterol in rats. Biochim Biophys Acta 1992; 1127: 141-6.

[11] Matsumoto N, Ishigaki F, Ishigaki A, Iwashin H, Hara Y. Reduction of blood glucose levels by tea catechin. Biosci Biotechnol Biochem 1993; 57: 525-7.

[12] Nagao T, Komine Y, Soga S, Meguro S, Hase T, Tanaka Y, Tokimitsu I. Ingestion of a tea rich in catechins leads a reduction in body fat and malondialehyde-modified LDL in men. Am J Clin Nutr 2005; 81: 122-9.

[13] Murase T, Nagasawa A, Suzuki J, Hase T, Tokimitsu I. Beneficial effects of tea catechins on diet-induced obesity: stimulation of lipid catabolism in the liver. Int J Obes 2002; 26: 1459-64.

[14] Osaki N, Harada U, Watanabe H, Onizawa K, Yamaguchi T, Tokimistu I, Shimasaki H, Itakura H. Effect of tea catechins on energy metabolisms in rats. J Oleo Sci 2001; 50: 677-82.

[15] Seto R, Nakamura H, Nanjo F, Hara Y. Preparation of epimers of tea catechins by heat treatment. Biosci Biotechnol Biochem 1997; 61: 1434-9.

[16] Nikaidou S, Ishizuka M, Maeda Y, Hara Y, Kazusaka A, Fujita S. Effect of catechins on mutagenesis of Salmonella typhimurium 
TA102 elicited by tert-butyl hydroperoxide ( $t$-BuOOH). J Vet Med Sci 2005; 67: 137-8.

[17] Sinha D, Bhattacharya RK, Siddiqi M, Roy M. Amelioration of sodium arsenite-induced clastogenicity by tea extracts in Chinese hamster v79 cells. J Environ Pathol, Toxicol Oncol 2005; 24: 12940.

[18] Muto S, Yokoi T, Gondo Y, Katsuki M, Shioyama Y, Fujita K, Kamataki T. Inhibition of benzo[a]pyrene-induced mutagenesis by epigallocatechin gallate in the lung of rpsL transgenic mice. Carcinogenesis 1999; 20: 421-4.

[19] Kuroda Y. Bio-antimutagenic activity of green tea catechins in cultured Chinese hamster V79 cells. Mutat Res 1996; 361: 179-86.

[20] Hayatsu H, Inada N, Kakutani T, Arimoto S, Negishi T, Mori K, Okuda T, Sakata I. Suppression of genotoxicity of carcinogens by epigallocatechin gallate. Prev Med 1992; 21:370-6.

[21] Cheng S, Ding L, Zhen Y, Lin P, Zhu Y, Chen Y, Hu X. Progress in studies on the antimutagenicity and anticarcinogenicity of green tea epicatechins. Chin Med Sci J 1991; 6: 233-8.

[22] Wang ZY, Cheng SJ, Zhou ZC, Athar M, Khan WA, Bickers DR, Mukhtar $\mathrm{H}$. Antimutagenic activity of green tea polyphenols. Mutat Res 1989; 223: 273-85.

[23] Jain AK, Shimoi K, Nakamura Y, Kada T, Hara Y, Tomita I. Crude tea extracts decrease the mutagenic activity of $\mathrm{N}$-methyl-N0-nitro$\mathrm{N}$-nitrosoguanidine in vitro and in intragastric tract of rats. Mutat Res 1989; 210: 1-8.

[24] Chang PY, Mirsalis J, Riccio ES, et al. Genotoxicity and toxicity of the potential cancer-preventive agent polyphenon E. Environ Mol Mutagen 2003; 41: 43-54.

[25] Isbrucker RA, Bausch J, Edwards JA, Wolz E. Safety studies on epigallocatechin gallate (EGCG) preparations Part 1: Genotoxicity. Food Chem Toxicol 2006; 44: 626-35.

[26] National Academy of Science report, 1981.

[27] Fine DH, Challis BC, Hartman P, Van Ryzin J. Endogenous synthesis of volatile nitrosamines: model calculations and risk assessment. IARC Sci Publ 1982; 41: 379-96.

[28] Hoffmann D, Adams JD, Brunnemann KD, Rivenson A, Hecht SS. Tobacco specific N-nitrosamines: occurrence and bioassays. IARC Sci Publ 1982; 41: 309-18.

[29] Scanlan RA. Formation and occurrence of nitrosamines in food. Cancer Res 1983; 43(5 Suppl): 2435s-40s.

[30] Perry P, Wolff S. New Giemsa method for differential staining of sister chromatids. Nature 1974; $251: 156-8$.

[31] Afzal M, Azfer MA. Standardization of sister chromatid exchange (SCE) assay for studying effects of environmental mutagen in human test system. Chem Environ Res 1994; 3: 67-70.

[32] Huang CC. Retinol (vitamin A) inhibition of dimethylnitrosamine $(\mathrm{DMN})$ and diethylnitrosamine (DEN) induced sister-chromatid exchanges in V79 cells and mutations in Salmonella/microsome assays. Mutat Res 1987; 187(3): 133-40.

[33] Sirianni SR, Huang CC. Comparison of S9 fractions from rats, mice, and Chinese hamsters to metabolize dimethylnitrosamine and diethylnitrosamine to intermediates that induce sister-chromatid exchanges in V79 cells. Mutat Res 1987; 188(1): 7-11.

[34] Johnson KW, Munson AE, Holsapple MP. Primary cellular target responsible for dimethylnitrosamine-induced immunosuppression in the mouse. Immunopharmacology 1987; 13(1): 47-60.
[35] Kim DH, Yang KH, Johnson KW, Holsapple MP. Suppression of in vitro antibody production by dimethylnitrosamine in mixed cultures of mouse primary hepatocytes and mouse splenocytes. Toxicol Appl Pharmacol 1987; 87(1): 32-42.

[36] Sharma RK, Jacobson-Kram D, Lemmon M, Bakke J, Galperin I, Blazak WF. Sister-chromatid exchange and cell replication kinetics in fetal and maternal cells after treatment with chemical teratogens. Mutat Res 1985; 158(3): 217-31.

[37] Tucker JD, Preston RJ. Chromosome aberrations, micronuclei, aneuploidy, sister chromatid exchanges and cancer risk assessment. Mutat Res 1996; 365:147-59.

[38] Hagmar L, Brogger A, Hansteen IL, et al. Cancer risk in humans predicted by increased level of chromosomal aberrations in human lymphocytes: Nordic study group on the health risk of chromosome damage. Cancer Res 1994; 54: 2919-22.

[39] Morse MA, Stoner GD. Cancer chemoprevention: principle and prospects. Carcinogenesis 1993; 1737-46.

[40] Dean BJ, Danford N. Assays for the detection of chemically induced chromosome damage in cultured mammalian cells. In: Venitt S, Parry JM. Eds. Mutagenicity testing. A practical approach. Oxford: IRL Press 1984; pp. 187-232.

[41] Gebhart E. Sister chromatid exchanges and structural chromosome aberration in mutagenicity testing. Hum Genet 1981; 58: 235-54.

[42] Ito Y, Maeda S, Souno K, Ueda N, Sugiyama T. Induction of hepatic glutathione transferase and suppression of 7,12dimethylbenz(a)anthracene-induced chromosome aberrations in rat bone marrow cells by sudan III and related azo dyes. J Natl Cancer Inst 1984; 73: 177-83.

[43] Ito Y, Maeda S, Fujihara T, Ueda N, Sugiyama T. Suppression of 7,12-dimethylbenz $(a)$ anthracene-induced chromosome aberrations in rat bone marrow cells after treatment with sudan III and related azodyes. J Natl Cancer Inst 1982; 69: 1343-46.

[44] Ito Y, Ohnishi S, Fujie K. Chromosome aberrations induced by aflatoxin B1 in rat bone marrow cells in vivo and their suppression by green tea. Mutat Res 1989; 222: 253-61.

[45] Ito Y, Nakamura Y, Nakamura Y. Suppression of aflatoxin B1- or methyl methanesulphonate-induced chromosome aberrations in rat bone marrow cells after treatment with S-methyl methanethiosulfonate. Mutat Res 1997; 393: 307-16.

[46] Kada T, Inoue T, Namiki M. In: Klekowski EJ, Ed Enviromental Mutagenisis, Carcinogenesis and Plant Biology, Praeger Scientific:, New York 1982; pp. 133-52.

[47] Jain AK, Shimoi K, Nakamura Y, Kada T, Hara Y, Tomita I. Crude tea extracts decrease the mutagenic activity of N-methyl-N0-nitro$\mathrm{N}$-nitrosoguanidine in vitro and in intragastric tract of rats. Mutat Res 1989; 210: 1-8.

[48] Sasaki YF, Imanishi H, Ohta T, Watanabe M, Matsumoto K, Shirasu Y. Suppressing effect of tannic acid on UV and chemically induced chromosome aberrations in cultured mammalian cells. Agric Biol Chem 1988; 52: 2423-28.

[49] Sasaki YF, Imanishi H, Ohta T, Watanabe M, Matsumoto K, Shirasu Y. Suppressing effect of tannic acid on the frequencies of mutagen induced sister-chromatid exchanges in mammalian cells. Mutat Res 1989; 213: 195-203.

[50] Shimoi K, Nakamura Y, Tomita I, Kada T. Bio-antimutagenic effects of tannic acid on UV and chemically induced mutagenesis in Escherichia coli B/r. Mutat Res 1985; 149: 17-23.

\section{(C) Al-Fify and Aly; Licensee Bentham Open.}

This is an open access article licensed under the terms of the Creative Commons Attribution Non-Commercial License (http://creativecommons.org/licenses/by$\mathrm{nc} / 3.0 /$ ), which permits unrestricted, non-commercial use, distribution and reproduction in any medium, provided the work is properly cited. 